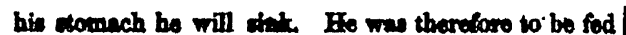
in the old athodax mannex. Ho was selsed by two or thres keopars an they ware celled, his month was wrenched open with aniron apoon or blunt chisel, frequently to the deanage of everal of hin teoth, his now was held tight, and the fluid poured dow the throat of the half sulfocated pationth who not nndar. ctending the necesity for these extreme attentions moald only become more alarmed, sespioione, and desormined in his opposition.

Irven when the comach pump wey ned as, is would bo when profeacional aid.was cought, the eamo.diffculky exinted as to the oponing the month, and to keep it open a gag was need, which was secured by etringa tied behind the head. Ueurly, howaver, the feoding proceses was trusted to tho attondenter, and it was not an unusul occurrence for pationts to leave an asylom minas a fow teeth.

To obriate these barbarities the late Dr. Balmanno invented his nasal appantess. It was regularly aned by him, and his succemor Dr. Hutcheson, and bas ince boen adopted in como of the English asylums. I am not cortain whother it is und in the genoral hoopitals of this conntry, but in cartain cases of tetanes, and in stricture of the coophagus it might be ueaful. Mr. Marthall, the medial superintendent of fomale patien as Colnoy Hetch, hus found it anower all the parposes it is intended for, and I balieve it has been tried at the Northampeon Genoral Innatic Houpital.

I have known pationss kept alive for weeks and ultimutaly sarod by moans of this instrumont, and in one inatance a gentlemen who had obatinately refused all nourishment and medicise for a protracted time antil bo wes upon the point of sinking, submitted quietly for several days to the introdaction of the tube, itting up in bed voluntarily, and requiring no holding of the hands or hoad. He had made a vow to atarve himalf, and kept it rigidly until a fow doses of modicine set his brain right, and a short argument, in ad. dition to a sharp appetite, conrinced him of the folly of his proceedings. As a genoral rule however, I have found that in cares of refusal of food, whare perversity and allennew of tamper ane exhibited, the introduction of the tube once or twice is sufficient. The pationt finding himself baffled in his determination, at once succumbe, disliking the inconvenience be is putting himsalf ta In other cases where there are phrtical canses to acconnt for the anorexia, medicine may bo adminintered by this instrument, for which purpose a mall elastic india rubber bag is provided cufficiently capecious to hold a good sized dranght. This is supplied in the caces, and fits the tabes tightly.

Mr. Wilkes' peper reminded mo of Dr. Balmanno, and of his being the phyician who firet invented and need the nesal apparatus among the insane, and it occurred to me that many who may have enployed it were not arrare of this fact Dr. Balmanno did much in his dag to improve the condition of the lunatic, and no ono had he lived would barro. wen a warmer interest In the groat progreas that has since his time been made in thir dopartment of medicine than he would have dona I am, Six, your obedient servant, Abingtow Abbey, Nor thangtom.

\section{Medical Certificates.}

Doar 8ir,-I believe every modicul practitioner who has been called upon to fill up a cortiflcate according to the form 16 and 18 Vice, c. 96, has falt the diffcalty of doing so eorrectly. For my own part I have nover yet een ono which did not require enendment The trouble thus ocanioned would bo removed if the letters of refenanoe, a, b, o, d, a, wero less microscopic; and if the directions wore marginal, and printed in rod ink.

Tho Commisuioners genorally return imperfect certifleate for correction : but it weems this is not inrariably done: but ourdy the doetrine that the Comminsionan wo not responnible for tho correctness of certificates nodar, which insene persons are confinod, [no Commisaioners Circular, Fob. 14th, 1855,] and that the reoponaibility, when they make no objow tion, sill rests with the "Buperintendents and othars" is uncound. At all ovents, it is both inconreniont and dangeroes.

$$
\text { I remnin, dear Sir, }
$$

Youre truly.

A SUPERINTENDENT.

\section{To the Editor of the Asylum Journal.}

Dear Sir,-Allow mo call the attention of super. intendents to an India rubber chamber utonsil, which Mearar. Mecintouh of Manchester have made at my onggestion, and which I think will be rery neeful for violent and excited patients, who could not be trasted with thow made of metal ar earthenwara.

One of the multifarions nees to which gutta perchs has been applied has been the manufacture of theas articles, but practically wo find, that besides the difficulty of keoping thern sweet, from the impossibility of using hot water to thom, thoy are easily broken when made of the ordinary strength, and if mado hearier they become serious weapons in the hands of excited pationts.

The India rubber ntenoils seem to be calculated to meet all those objections, for while of sufficient strength to resist the ordinary rough usage of an asylum, they are uneless as offensive wespons, and boiling water may be employed to cleanse them.

The price chargod at present is rather high, bat Mecorser Mrointosh consider that they shall be enabled to offer them at a lower rate if there is any demend for them.

$$
\text { Yours faithfully, }
$$
JAMES WILKES.

Stafford Cownty Imatic Arylum.

Trial and Conviction of a Busband for the ill-treatmat of his Lunatic Wife.

At the Deron Spring Assizes on the 17th alt, before Mr. Justice Crowder, Joha Rusalle wes charged with abusing, ill-treating, and wilfully neglecting Amelia Rundle, his wifo, a lunatic.

Mir. Stock stated that the prosecution was inatiturd by the Commiosionera in Lunucy; and that thoy ware fully detarmined to prosecute in all cames of a vimilur 
nature which might come under their noticen in order thet the belpleen lunatic might receive evary protection which the Inw would afford. He called the following vitneseses.

Ann Hill reted that the prisonier's wife, who was now doad, was her daughter. . She had been married to the prisoner eloven years. Some timo previous to the 7 th of October, tho day apon which she was edmitted inco the lunatio aylum, she met her in Doroaport, and sho showed her hor arms, which were much saratched. They went togother to the priconery bonse in St Anbyn otreet, and witneis told the prisoner that ho ought to be shamed of himsalf to ill-treat her, upon which he ardered her out of his bowes. The privoner struck his wife with a hearth brosh, and aid ho would mako no more of killing ber than ho woald of killing a rabbit. Ho afterwands remored to Monument On one occasion he refued his wife and hor (ritneen) admittance, and they went array. The prisoner's wife had had no rest the previons night, and on returning to the bopes the fell down throngh weaknow At that timo witnem obeerved shat her daughter's mind was diutarbed.

Ann King, the wife of decaced lunatio's brother, remombered the period when the privoner lived in Monument street. She had come convenation with his wife on one ocension, and aftarwards took her to her mother's house $\mathbf{A}$ short tinse afterwands the witnew waw the priponer and aked him whare his wife was, when he mede woe of a disgueting expreesion, and said he hoped sho would rot in pricon or be trensported. On another cocksion when she went to the prisoner's honse, the priconer's wife came down whirs with her stays outside har drese, and looking very wild. Bhe aid "Jeck" had beween hor, upon which the privoner langhed. She then showed the bruises on har shosalders and brenct, and said to the prisoner " you know you did it:" to which ho replied "Jou wero going to throw conls at me." Ho at first denied having strack her, but he subsequently admitted that he struck her with a brush.

Jane Butcher, a widow, residing in 8t. Aubynareet, recollectod when the prisoner lived next door to her. On one occarion abe beard a violent "screeching" in the prisoner's house, and she ran in and found his wifo crouched down in a corner: she said "the brute hes kicked me with his boota" Witness had often heard him talk of the state of his wife's mind, and she remonotrated with him: ho told him he ought to have a person to take care of her wo the was incapable of doing anything herself, but he repliod that it was no more harm to kill her than it was to kill a rabbit. Witnes had noticed the alterations in the wife's mind como monthe proviously ; cometimes the took things from vitnes's hones which did not belong to her. In reference to these oceurronces the priconer had told witnese be conld not be respon. sible for her act in the state of mind she was in.

Mir. Tripe, enrgeon, of Devonport, ctated that he Ind examined the prisoner's wife. He told her abe would be taken to a place where ber mental and bodily beelth woald be taken care of : sho replied that she bnow she mes not in a sound ctato of mind, and would be glad to 80 to a place whare ahe rould be eafo from the attecks of her broband : tho bared her left arm and thoulder, and showed comen braines, and, pointing to her busbend, said "he did it" Witwes we of opiaion that the bruices were produced by a blant inctrument. He found severnal bruices on the abdomen and thights, the hips, the loft arm; and the buttocks, the latter be thought might have been infticted by a kick: a megiviate was present at the timo, and sort of change was made againat the privoner, upon which he denied it, and took up a browh which ho waid she might have ran against when he was defending himwolf from her attucks Witness was of opinion it was a confirmed case of lunscy.

Dr. Buchonill atated that he was the medical axparintendent of the Deron County Lanntic Asylam. He examined Amelis Randle on the 8th of October, the day after her admiseion, and he obwerved the bruises which Mr. Tripe had deecribed. He thought that the bruices conld not have been self infticted. The condition of the patient as to bor mind wat docas of the facultien In his opinion sho had been in a utwe of unsound mind for a year or more. She had sufiened an attack of apoplexy and was paralyead. On the 19th of December she was delivened of a will bow child; and on the 12th of January tho died. About the end of November the privoner callod at the Anglum, and witness sent for him to his office, and and " Your wife has told mo that the injurios from which ohe enfiered when she was brought hore were inticted by your violence. If that was the cave, your conduct was bratal and unmanly." Prisoner repliod that it was true, and that he was sorry for it.

The defendant, in addreating the jury, asid hil wife was in tho habit of falling down the tairs which cansed the bruices; and he asked why the cano was not brought before tho magictrates when she was alive? Ho admitted striting her on the ahoulder: and atated that she had thrown him inso great oxpences, and on one occasion sho had pat poicon into his tea-pot.

A verdict of Guilty having been found, The Jadge said that he should reverve the point of law an to whether the prisoner could be decmed, in the word of the ctevates to have the care and change of his wife. For this parpose he contenced the prisoner to wix months' imprienment with hard labour; and bo divided the term, passing centence for Are months and a fortnight for the common anault, and the remining fortnight for the offence changed ander the lunacy statute.

\section{Anyluese for Crivinal Luratice.}

In the House of Iorde on the 9th nltima, Lard

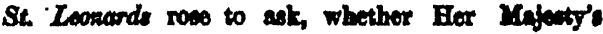
Government had any intention to erect aylams for criminal lunatics ? Under the exioting asutem a privon frequently became whes it was norer intended to be-an asylum for lanntios; and bo considerod, thas as it was improper to convert a prison into an anjium, 50 it was improper to make an esylum a privon, for the rules and regulations of the one and the other wore altogether differeat.

Ho was awrus that ho might be mot by a dattenent 